\title{
Ultrasound Assisted Synthesis Of Pyrazolone Derivatives
}

\author{
Badie A. Ahmed Jasim A. Abdullah \\ Department of Chemistry / College of science
}

\section{Mosul University}

\section{الخلاصة}

تم ازدواج ملح الديازونيوم ل4-أمينو-5,1- ثنائي مثيل-2- فنيل-H1- بايرازول 5-اون (4-أمينوأنتي بايرين) مع أسيتوخلات الأثيل وبنزويل خلات الأثيل في الوسط القاعدي التئي

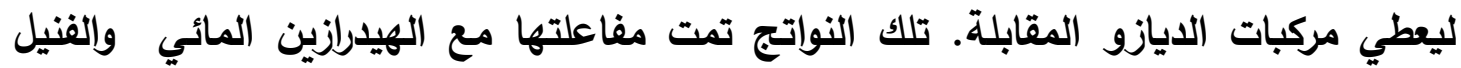
هيدرازين بطريقة الموجات فوق الصوتية لتعطي مثتقات البايرازولون(ا) بنسبة عالية.

\begin{abstract}
The diazonium salt of 4-amino-1,5-dimethyl-2-phenyl-1H-pyrazol2-one (4-aminoantipyrine) was coupled with ethylacetoacetate and ethyl benzoylacetate to give the corresponding diazo compounds under basic media. These products were allowed to react with hydrazine hydrate and phenylhydrazine under Ultrasound method to give pyrazolone derivatives (I) in high yields.
\end{abstract}

Keywords: Ultrasound, Pyrazolone, Ethylaceto and/or Ethylbenzoylacetate

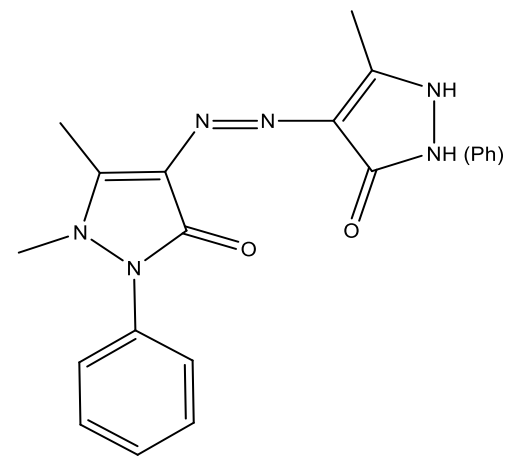

(I)

Presented at the second conference on Chemistry, University of Mosul, college of Education, 17-18 Novamber-2013. 


\section{INTRODUCTION:}

Heterocyclic compounds are acquiring more importance in recent years because of broad pharmacological activities. Pyrazolone have a particular value due to both their broad spectrum of biological activity and their wide ranging utility as synthetic tools in the design of various bioactive molecules. Pyrazolone is a five-membered lactam ring which contains two nitrogens and a ketone in the same molecule ${ }^{(1,2)}$. The chemistry of pyrazolone was started by knorr in 1883 and reported the first pyrazolone derivative $\mathrm{e}^{(3)}$. The pronounced synthetic utility of heterocycles in the area of pharmaceuticals ${ }^{(4-6)}$, dyes and pigment ${ }^{(7)}$, technology ${ }^{(8,9)}$ and natural products $^{(10)}$ Pyrazolone or 4-aminoantipyrine derivatives are interesting series of heterocyclic compounds, which have been shown to be diverse biological properties such as cytotoxic, anti-inflammatory ${ }^{(11)}$, antimicrobial $^{(12)}$, antioxidant, antifungal ${ }^{(13)}$, antiviral, antitumor ${ }^{(14)}$, analgesic ${ }^{(15,16)}$. The approach reported here deals with the synthetic of some new pyrazolones start in 1,3-dicarbonyl compound such as ethylacetoacetate and ethylbenzoylacetate after coupled with 4-amino-1,5-dimethyl-2-phenyl1H-pyrazol-2-one (4-aminoantipyrine) and then reacted with hydrazine or phenylhydrazine to give pyrazolone derivatives using simple methodology, i.e Ultrasound and benign multicompenent procedure. Furthermore conventional methods.

\section{EXPEREMENTAL:}

Melting point were determined on a Stuat melting apparatus SMP30 Infrared spectra were recorded on a Bruker, FT-IR Spectrophotometer Tensor 27, Germany, and a biotech Engineering, FT-IR-600, U.K., using $\mathrm{KBr}$ discs. Ultra-Violet spectra were recorded on Shimadzu UV - 1650 pc, UV-Visible spectrophotometer, Japan, using chloroform as a solvent.

Synthesis of ethyl 2-((1,5-dimethyl-3-oxo-2-phenyl-2,3-dihydro- $1 H$ pyrazol-4-yl)diazenyl)-3-oxobutanoate(3) and ethyl 2-((1,5-dimethyl3-oxo-2-phenyl-2,3-dihydro-1H-pyrazol-4-yl)diazenyl)-3-oxo-3phenylpropanoate $(4)^{(17)}$.

A well stirred solution of 4-aminoantipyrine(1) $(2.03 \mathrm{~g}, 0.01 \mathrm{~mol})$ in conc. $\mathrm{HCl}(3 \mathrm{~mL})$ and $2 \mathrm{~mL} \mathrm{H}_{2} \mathrm{O}$ was cooled in ice-bath and diazotized with the solution of $\mathrm{NaNO}_{2} \quad\left(0.35 \mathrm{~g}, 5.1 \mathrm{mmol}\right.$ in $\left.5 \mathrm{~mL} \mathrm{H} \mathrm{H}_{2} \mathrm{O}\right)$. The cold diazonium solution was added slowly to a well stirred of ethylacetoacetate $(1.3 \mathrm{~g}, 0.01 \mathrm{~mol})$ or ethylbenzoylacetate $(1.92 \mathrm{~g}, 0.01$ mol) in absolute ethanol $(25 \mathrm{~mL})$ containing sodium acetate $(0.82 \mathrm{~g}, 0.01$ mol). The reaction mixture was stirred for another $2 \mathrm{~h}$. The crude product was filtered off, dried well and recrystallized from ethanol to give corresponding compounds (3 or 4 ), that yield (84\%). 
Synthesis of 1,5-dimethyl-4-((5-methyl-3-oxo-2,3-dihydro-1 $H$-pyrazol -4-yl)diazenyl)-2-phenyl-1H-pyrazol-3(2H)-one(5) and 1,5-dimethyl4-((3-oxo-5-phenyl-2,3-dihydro-1 $H$-pyrazol-4-yl)diazenyl)-2-phenyl$1 H$-pyrazol-3(2H)-one $(6)^{(18)}$.

A solution of hydrazine hydrate $(0.05 \mathrm{~g}, 0.001 \mathrm{~mol})$ in ethanol $(0.8$ $\mathrm{mL}$ ) was added dropwise to the corresponding $\boldsymbol{B}$-ketoester compounds (3) $(0.344 \mathrm{~g}, 0.001 \mathrm{~mol})$ or $(4)(0.406 \mathrm{~g}, 0.001 \mathrm{~mol})$ in a $25 \mathrm{~mL}$, round bottom flask. The mixture was irradiated in the water bath of an ultrasonic cleaner for $30 \mathrm{~min}$. The cold reaction mixture was treated with ethanol, ether, or pet. ether (80-100). The solid product was filtered and dried. The solid obtained was pure and did not need recrystallization, that yield $(90 \%)$ for $(5)$ and $(95 \%)$ for $(6)$, Tables $(1,2)$.

Synthesis of 1,5-dimethyl-4-((5-methyl-3-oxo-2-phenyl-2,3-dihydro$1 H$-pyrazol-4-yl)diazenyl)-2-phenyl-1H-pyrazol-3(2H)-one(7) and 1,5-dimethyl-4-((3-oxo-2,5-diphenyl-2,3-dihydro-1 $H$-pyrazol-4yl)diazenyl)-2-phenyl-1 $H$-pyrazol-3(2H)-one $(8)^{(18)}$.

Follow the same procedure for preparation of compound(5) and (6). A solution of phenylhydrazine $(0.108 \mathrm{~g}, 0.001 \mathrm{~mol})$ in ethanol $(0.8 \mathrm{~mL})$ was added dropwise to the corresponding $\boldsymbol{B}$-keto ester compounds(3) $(0.344 \mathrm{~g}, 0.001 \mathrm{~mol})$ or $(4)(0.406 \mathrm{~g}, 0.001 \mathrm{~mol})$ in a $25 \mathrm{~mL}$, round bottom flask. The mixture was irradiated in the water bath of an ultrasonic cleaner for $30 \mathrm{~min}$. The cold reaction mixture was treated with ethanol, ether, or pet. ether (80-100). The solid product was filtered and dried. The solid obtained was pure and did not need recrystallization, that yield $(86 \%)$ for $(7)$ and $(88 \%)$ for $(8)$, Tables $(1,2)$.

\section{RESULTS AND DISCUSSION}

In this paper the intermediate 1,3-dicarbonyl compounds, ethyl 2((1,5-dimethyl-3-oxo-2-phenyl-2,3-dihydro-1H-pyrazol-4-yl)diazenyl)-3oxobutanonoate(3)and ethyl 2-((1,5-dimethyl-3-oxo-2-phenyl-2,3dihydro -1H-pyrazol-4-yl)diazenyl)-3-oxo-3-phenylpropanoate(4) used for synthesis of pyrazolone diazines derivatives(5-8) were prepared by the coupling of diazonium salt(2) with ethylacetoacetate and ethylbenzoyl acetate in an alkaline medium to get yellow and orange coloured compounds. The diazonium salt of 4-aminoantipyrine have been found to be easy to couple with 1,3-diketone. Since, 4-aminoantipyrine possessing electron-donating group give excellent yields ${ }^{(18)}$. The compound(3), which show absorptions $v \mathrm{~cm}^{-1}$ at $1707(\mathrm{C}=\mathrm{O}),(\mathrm{C}=\mathrm{O})$ (ester), and 1655 $(\mathrm{C}=\mathrm{O})$ conjugated amide and $(\mathrm{C}=\mathrm{C}), 1484(\mathrm{~N}=\mathrm{N}), 2929,2987(\mathrm{C}-\mathrm{H})$ aliph. $3153,3187(\mathrm{Ar}-\mathrm{H}), \lambda \max 332 \mathrm{~nm} \mathrm{n}-\pi^{*}$ transition. Compound (4) show absorption $v \mathrm{~cm}^{-1}$ at $1710(\mathrm{C}=\mathrm{O})$ and $(\mathrm{C}=\mathrm{O})$ ester, $1676(\mathrm{C}=\mathrm{O})$ conjugated amide and $(\mathrm{C}=\mathrm{C}), 1486(\mathrm{~N}=\mathrm{N}), 3178,3284(\mathrm{Ar}-\mathrm{H}), \lambda \max 322 \mathrm{~nm} \mathrm{n}-\pi^{*}$ 
transition. The compound (3) and (4) was converted to pyrazlone diazine derivatives(5-8) by reacted compounds (3) and (4) with hydrazine hydrate and phenylhydrazine via.

ultrasound irradiation compounds (5 and 6) get from compounds (3) and (4) were reacted with hydrazine hydrate under ultrasound irradiation. Compound(5), which show absorption $v \quad \mathrm{~cm}^{-1}$ at $1697 \quad(\mathrm{C}=\mathrm{O})$ unconjugated amide, $1647(\mathrm{C}=\mathrm{O})$ conjugated amide, $(\mathrm{C}=\mathrm{N})$ and $(\mathrm{C}=\mathrm{C})$, 1494(N=N), 2925,2979 (C-H) 3055,3178 (Ar-H) and $3462(\mathrm{~N}-\mathrm{H}), \lambda \max$ $343 \mathrm{~nm} \mathrm{n}-\pi^{*}$ transition ${ }^{(19)}$. The compound(6) show absorption $v \mathrm{~cm}^{-1}$ at $1701(\mathrm{C}=\mathrm{O})$ uncojugated amide, $1662(\mathrm{C}=\mathrm{O})$ conjugated amide, $(\mathrm{C}=\mathrm{N})$ and $(\mathrm{C}=\mathrm{C}), 1497(\mathrm{~N}=\mathrm{N}), 2866,2927(\mathrm{C}-\mathrm{H}), 3057,3178(\mathrm{Ar}-\mathrm{H})$ and 3431 $(\mathrm{N}-\mathrm{H}), \lambda \max 346 \mathrm{~nm} n-\pi^{*}$ transition. While $(\mathrm{C}=\mathrm{N})$ Peaks disappeared in compounds ( 7 and 8 ) because that, found tautomarism in the pyrazolone scheme(1) Compounds (7 and 8) was prepared from compounds (3 and 4) when treated with phenylhydrazine . Compound (7) show absorption $v$ $\mathrm{cm}^{-1}$ at $1668(\mathrm{C}=\mathrm{O})$ conjugated amide, $1580(\mathrm{C}=\mathrm{C}), 1506(\mathrm{~N}=\mathrm{N}), 3452$ $(\mathrm{N}-\mathrm{H}) 2858,2927(\mathrm{C}-\mathrm{H})$, and 3024,3078 (Ar-H). $\lambda \max 352 \mathrm{~nm} \mathrm{n}-\pi^{*}$ transition. Compound (8) show absorption $v \mathrm{~cm}^{-1}$ at $1664(\mathrm{C}=\mathrm{O})$ conjugated amide, $1582(\mathrm{C}=\mathrm{C}), 1513(\mathrm{~N}=\mathrm{N}), 3443(\mathrm{~N}-\mathrm{H}), 2841,2922(\mathrm{C}-$ $\mathrm{H}), 3025,3183$ (Ar-H) $\lambda \max 354 \mathrm{~nm} \mathrm{n}-\pi^{*}$ transition.

Physical and spectral data are listed in Table $(1,2)$.<smiles>O=c1cc[nH][nH]1</smiles>

$\mathrm{NH}$-form

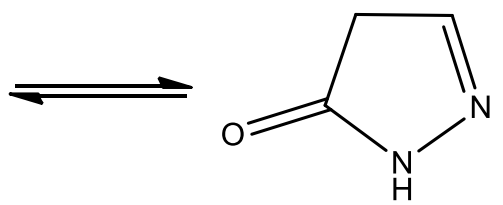

$\mathrm{CH}$-form<smiles>Oc1ccn[nH]1</smiles>

$\mathrm{OH}$-form

Scheme (1) 
Badie A. Ahmed \& Jasim A. Abdullah

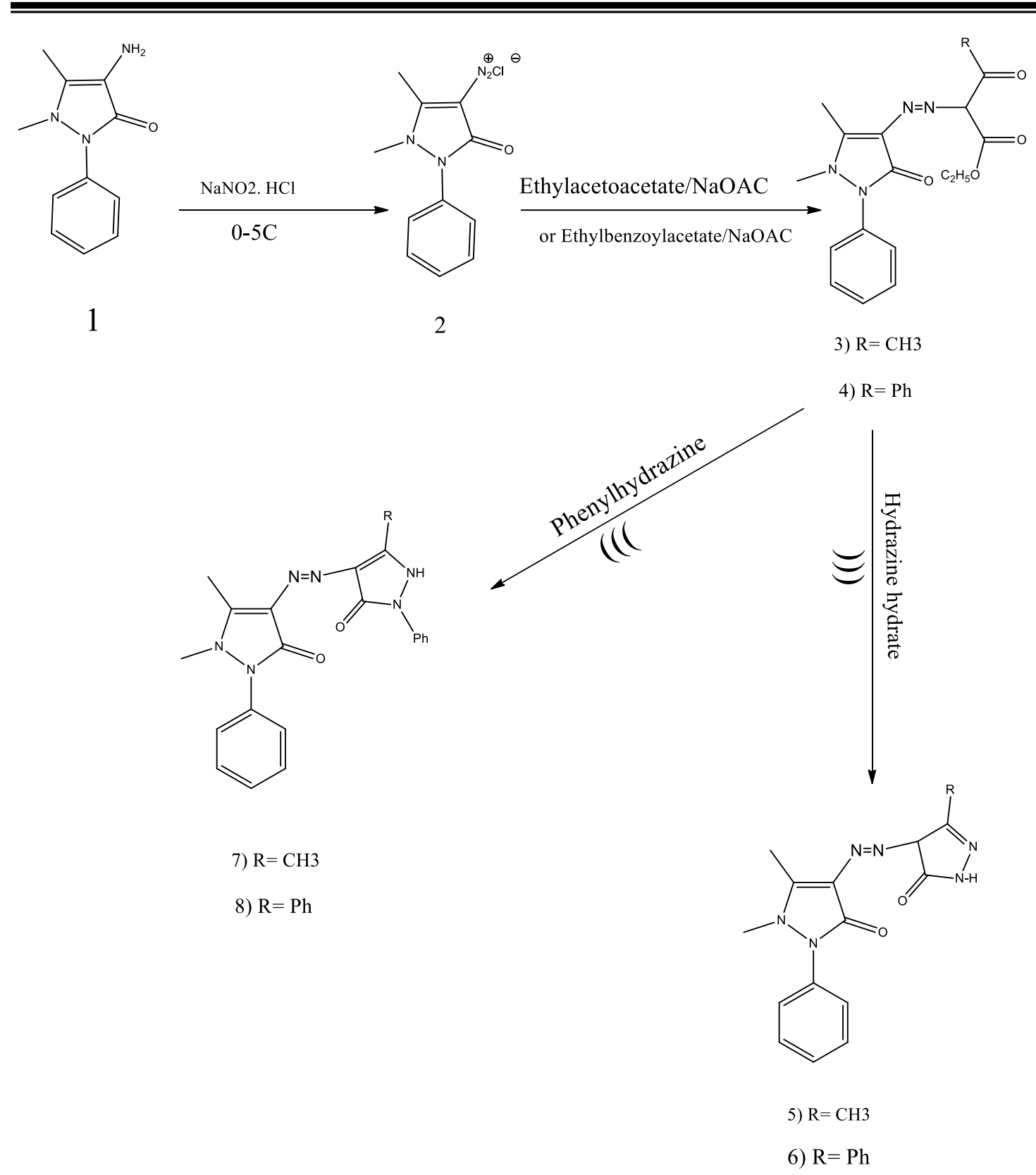

Scheme(2) 
Table (1): Physical data of compounds(3-8).

\begin{tabular}{|c|c|c|c|}
\hline Comp. No. & Molecular formula & Yield \% & m.p. ('C) \\
\hline $\mathbf{3}$ & $\mathrm{C}_{17} \mathrm{H}_{20} \mathrm{~N}_{4} \mathrm{O}_{4}$ & 84 & $174-177$ \\
\hline $\mathbf{4}$ & $\mathrm{C}_{22} \mathrm{H}_{22} \mathrm{~N}_{4} \mathrm{O}_{4}$ & 84 & $126-129$ \\
\hline $\mathbf{5}$ & $\mathrm{C}_{15} \mathrm{H}_{16} \mathrm{~N}_{6} \mathrm{O}_{2}$ & 90 & $191-193$ \\
\hline $\mathbf{6}$ & $\mathrm{C}_{20} \mathrm{H}_{18} \mathrm{~N}_{6} \mathrm{O}_{2}$ & 95 & $182-185$ \\
\hline $\mathbf{7}$ & $\mathrm{C}_{21} \mathrm{H}_{20} \mathrm{~N}_{6} \mathrm{O}_{2}$ & 86 & $198-200$ \\
\hline $\mathbf{8}$ & $\mathrm{C}_{26} \mathrm{H}_{22} \mathrm{~N}_{6} \mathrm{O}_{2}$ & 88 & $238-240$ \\
\hline
\end{tabular}

Table (2): Spectral data of compounds (3-8)

\begin{tabular}{|c|c|c|c|c|c|c|c|c|c|c|}
\hline \multirow[b]{2}{*}{$\begin{array}{c}\text { Comp. } \\
\text { No. }\end{array}$} & \multicolumn{9}{|c|}{ IR $V \mathbf{c m}^{-1}, \mathrm{KBr}$} & \multirow[b]{2}{*}{$\begin{array}{c}\text { U.V. } \\
\mathbf{C H C l}_{3} \\
\lambda \max \end{array}$} \\
\hline & $\begin{array}{c}\mathrm{C}=\mathrm{O} \\
\text { unco. } \\
\text { ami }\end{array}$ & $\begin{array}{l}C=O \\
\text { conj. } \\
\text { amid }\end{array}$ & $\begin{array}{c}\mathrm{C}=\mathrm{O}, \\
\mathrm{C}=\mathrm{O} \\
\text { est. }\end{array}$ & $\mathbf{C}=\mathbf{N}$ & $\mathbf{N}=\mathbf{N}$ & $\mathrm{C}=\mathrm{C}$ & $\begin{array}{l}\text { C-H } \\
\text { ali. }\end{array}$ & $\begin{array}{c}\text { Ar- } \\
\mathbf{H}\end{array}$ & N-H & \\
\hline 3 & ----- & 1655 & 1707 & & 1484 & 1655 & $\begin{array}{l}2929, \\
2987\end{array}$ & $\begin{array}{l}3153, \\
3187\end{array}$ & ------- & 332 \\
\hline 4 & & 1676 & 1710 & ------- & 1486 & 1676 & ------ & $\begin{array}{l}3178 \\
3284\end{array}$ & ------- & 322 \\
\hline 5 & 1697 & 1647 & & 1647 & 1494 & 1647 & $\begin{array}{l}2925, \\
2979\end{array}$ & $\begin{array}{l}3055 \\
3178\end{array}$ & 3462 & 343 \\
\hline 6 & 1701 & 1662 & ------- & 1662 & 1497 & 1662 & $\begin{array}{l}2866, \\
2927\end{array}$ & $\begin{array}{l}3057 \\
3178\end{array}$ & 3431 & 346 \\
\hline 7 & ----- & 1668 & ------ & ----- & 1506 & 1580 & $\begin{array}{l}2858, \\
2927\end{array}$ & $\begin{array}{l}3024, \\
3078\end{array}$ & 3452 & 352 \\
\hline 8 & ----- & 1664 & ------- & & 1513 & 1582 & $\begin{array}{l}2841 \\
2922\end{array}$ & $\begin{array}{l}3025, \\
3183\end{array}$ & 3443 & 354 \\
\hline
\end{tabular}

\section{REFERENCES:}

1) Zeinab, N. Minoo, D. Mohsen, N . Hamid, R. and Ayoob, B.; Tetrahedron. 2012, Vol. 68, pp.738-748.

2) Kim Carey Potgieter, Nelson Mandela Metropolitan University. 2009, 26-27.

3) Kumar, L. Thakur, C. and Sharma, V.; IJRPS. 2012,2(2), pp. 1322.

4) Manfred, V. and Hans-Martin, K.; Br.J.clin.Pharmac., 1980, 10, 2995-3085.

5) Tian, C. Radhia, B. Jinho, K. Karen, S. Daniel, A. Richard, I. Donald, R. Robert, J. and Richard, B.; Journal of medicinal chemistry. 2011, 10, 1021, A, B. 
6) Hayam, H. Hebat-Allah, S. Eman, M. H. Eman, M.F.Der Parma Chemica, 2011,3(1). 31-41.

7) Luiza, R. and Raquel, R. Pharmaceuticals, 2012, 5, 317324.

8) Nadeem, S. Arshad, M. Waquar, A. Shamsher.; IJPSDR 2009,1(3),136-143.

9) Julee, P. Dhrubo, J. and Kamal, M. Journal of Applied Pharmaceutical science 2011, 1(4), 115-120.

10) Sankpal, S. Deshmukh, M. Abhule, P. Salunkhe, D. Alsundkar, K. Patil, P. Chandam, D. Jagadale, S. Mulik, A. and Rokade, S. ; J. Chem. Pharm. Res., 2010, 2(5). 574-579.

11) Yassin, F. A.; J. Microbial. Antimicrob. 2010, 2(7). Pp. 93-99.

12) Nusrat, Binta Ahasan and Md. Rabiul Islam, Bangladesh, J. Pharmaco,. 2007, 2, 81-87.

13) Xiao-Hong, W. Xia-Kun, W. Yong,-Ju, L. Zhi, S. Jian,-Ye, Z. Li-Ming, C. and Li-Wu, F.; Chinese Journal of Cancer. 2010, Vol. 10, 12, 980-983.

14) Supryia, M. Nilanjan, P. Neeraj, K. and Sharm, P.; T. Ph. Res., 2010, 3, 51-59.

15) Chatrabhuji, PM. Nimavat, Ks. Vyas, KB. And Undavia, NK. RJPBCS, 2010, Vol. 1, 3, 451-455.

16) Vikrant, J. International. Journal of Theoretical and Applied Sci.; 2009, 1(1), 54-56.

17) Metwally, M. Yaser, A. Gouda, M. Ammar,N. and Khalil, A.; Int. J. Modern Org. Chem. 2012, 1(3), 213-226.

18) Amal, A. Fatma, E. and Hassan, M. Journal of Saudi Chemical Society.; 2010, 14, 287-299.

19) Thaker, K. Zalavadiya, P. and Joshi, H.; J. Sci. I. R. Iran, 2005, vol. 16, No.2, 139-144. 